\title{
OPEN
}

\section{Author Correction: Baleen whale acoustic presence and behaviour at a Mid-Atlantic migratory habitat, the Azores Archipelago}

Miriam Romagosa $\mathbb{D}^{\text {, }}$ Mark Baumgartner, Irma Cascão ${ }^{\mathbb{D}}$, Marc O. Lammers, Tiago A. Marques, Ricardo S. Santos \& Mónica A. Silva $(1)$

Correction to: Scientific Reports https://doi.org/10.1038/s41598-020-61849-8, published online 16 March 2020

This Article contains typographical errors in the Acknowledgements section.

"through research projects TRACE (PTDC/MAR/74071/2006), MAPCET (M2.1.2/F/012/2011) and AWARENESS (PTDC/BIA-BMA/30514/201), co-funded by FEDER, COMPETE, QREN, POPH, ERDF, ESF, the Lisbon Regional Operational Programme, and the Portuguese Ministry for Science and Education. Funding for publication fees was provided by Project AWARENESS (PTDC/BIA-BMA/30514/201)"

should read:

"through research projects TRACE (PTDC/MAR/74071/2006), MAPCET (M2.1.2/F/012/2011) and AWARENESS (PTDC/BIA-BMA/30514/2017), co-funded by FEDER, COMPETE, QREN, POPH, ERDF, ESF, the Lisbon Regional Operational Programme, and the Portuguese Ministry for Science and Education. Funding for publication fees was provided by Project AWARENESS (PTDC/BIA-BMA/30514/2017)"

(c) Open Access This article is licensed under a Creative Commons Attribution 4.0 International License, which permits use, sharing, adaptation, distribution and reproduction in any medium or format, as long as you give appropriate credit to the original author(s) and the source, provide a link to the Creative Commons license, and indicate if changes were made. The images or other third party material in this article are included in the article's Creative Commons license, unless indicated otherwise in a credit line to the material. If material is not included in the article's Creative Commons license and your intended use is not permitted by statutory regulation or exceeds the permitted use, you will need to obtain permission directly from the copyright holder. To view a copy of this license, visit http://creativecommons.org/licenses/by/4.0/.

(c) The Author(s) 2020 